\title{
Periodontal Disease a Challenge
}

\author{
Jose Ricardo Kina* \\ Department of Surgery and Integrated Clinic, The University of Unidade de Ensino Superior Dom Bosco, Brasil
}

Submission: February 02, 2018; Published: February 23, 2018

*Corresponding author: Jose Ricardo Kina, Department of Surgery and Integrated Clinic, Division of Periodontics, The University of Unidade de Ensino Superior Dom Bosco, Sao Luis, Brasil, Email: kinajr@hotmail.com

\section{Opinion}

To treat or to prevent any disease always will be necessary eliminating all etiologic factors, or/and improving host local defense or/and general resistance against the entire etiologic factors, or/and establishing control in all etiologic factors at levels below the degree of resistance of the host to promote homeostasis in diseased areas through a long stated period. To establish a treatment plan that would be used in treating a disease, it is essential to understand the vital role of the etiological agents that initiated the disease. Periodontal disease always results from the association of the bacteria with many other etiologic factors as local and/or general risk factors, which are indispensable elements to establish the disease status. The diagnostic of the etiological agents of the periodontal disease is critical, due to the necessity of the association among a susceptible host and the various etiological agents, such as bacteria, and several local and/or general predisposing risk factors to induce the disease. Nevertheless the preponderance of all forms of periodontal diseases is treated as microorganisms-induced dependent, since the bacteria induce a defensive inflammatory mechanism against the bacteria and their toxic materials. The inflammatory process inactivates the bacteria, but produces the liberation of bacterial and neutrophils products such as enzymes, which induce periodontal tissue destruction by lytic activities. Therefore, the characteristics of the periodontal disease are: presence of gingival inflammation, ulceration of the junctional epithelium, loss of connective tissue and alveolar bone, causing apical migration of the junctional epithelium. Then periodontal disease is a defensive mechanism which avoids penetration of bacteria into the periodontal tissues, to prevent infections and septicemia. However as a side effect this mechanism of protection induces the formation of periodontal pockets, the major pathognomonic sign characteristic of a periodontal disease: an increase in the depth of gingival sulcus, thereby, creating a favorable anaerobic environment to be infected, as a result of the recurrent contamination by the several species or the combination of the species as exogenous anaerobic and facultative bacteria (periodontopathogenic bacteria). These putative periodontal pathogens and their products may induce substantial pathological alterations, essentially in root surface exposed to the contaminated periodontal pocket. In addition, due to the direct contact between the bacteria that infect the periodontal pocket with the ulcerated epithelium of the pocket could occur the anachoresis, a process associated with dissemination of the microorganisms or/and toxics products into blood stream, assisting or causing infection in the various vital organs. Although all destruction of the periodontal tissues during the evolution of the periodontal disease has analogous features, the developmental origin triggered by the association between the bacteria and the various predisposing risk factors, may be different, and inherent to each person, depending on the host's susceptibility, which does not always present an identical susceptibility to the various local and/or general predisposing risk factors. The majority of the periodontal disease cause localized destruction fundamentally depending on the association of the opportunist bacteria and several intrinsic local predisposing risk factors. The local predisposing risk factor may provoke a mechanical vulnerability in the periodontal tissues around a tooth, and/or may assist in bacterial retention, development and organization, in order to originate periodontal tissue destruction. Generalized periodontal disease may arise, when the systemic predisposing risk factor interferes with the host's defense mechanism against the opportunist bacteria, once the host factor operates in all periodontal tissues. The predisposing risk factor may statistically increase the occurrence of a disease, but it does not cause the disease. Predisposing risk factors may be defined as systemic factors, local factors, behavioral factors in nature, and factors related to the development of the acquired alterations that involve the periodontal tissues. All types of periodontal disease are multifactorial diseases, which progress through successive destructive acute phases, always interposed, by reparative chronic phases. Evidence of the reparative phase of periodontal disease is possible being verified in histological analyzes of untreated periodontal pockets as cementum and the gingival-attached connective tissue zone, separating the bottom of the periodontal pocket from the underlying destructed alveolar bone which often presents a repaired cortical bone at a variety of levels defending the cancellous bone. In untreated periodontal pockets is possible it is possible to verify histologically that the gingival attached connective tissue of the biologic width should be destroyed but it will always be present intact immediately above of the destructed alveolar bone. After each successive destructive acute phase, variations in the quantity and quality of the etiological 
agents and the predisposing risk factors would arise. Despite this, the transitory, short, destructive but protective acute phase always ceases being always followed by a long chronic quiescent reparative phase. This fact demonstrates that, etiological agents and predisposing risk factors during the periodontal disease progression, acquired better quality and quantity, but could not be able to maintain the periodontal disease destructive phase activity all the time. Possibly, periodontal disease restart and evolves when at a specific time an intrinsic temporary fragility, essential and specific for each individual, supports involved etiological agents to initiate the destructive acute phase of periodontal disease to establish the progression of the periodontal disease. Because of this relationship between individuals and the several possible etiological factors of periodontal disease that may vary for each of them, it is very difficult to establish which etiological factors are acting to develop the disease in a particular individual and in a determined moment. If the etiological factors of periodontal disease were the same for all individuals and if the disease did not progress through destructive periodic acute outbreaks interspersed with chronic reparative outbreaks it would be simpler to establish an effective treatment plan. The unique etiological factors that will always be present to cause periodontal disease for all individuals are bacteria. Perhaps for this reason periodontal disease treatment is based on the control of bacteria and their products. However, is this concept of treatment able to treat periodontal disease effectively? And the other multifactor's of periodontal disease that in association with bacteria trigger the disease should not be focused? Periodontal disease is really a challenge [1-3].

\section{References}

1. Kina JR, Kina J, Kina EF, Kina M, Soubhia AM (2008) Presence of bacteria in dentinal tubules. J Appl Oral Sci 16(3): 205-208.

2. Kina JR, Suzuki TY, Kina J, Kina M, Kina EF (2013) Reparative phase events on periodontal disease progression: interpretation and considerations. Int J Microbiol Res 5(4): 439-444

3. Kina JR, Suzuki TY, Kina J, Kina M, Kina EF (2016) Non-inflammatory destructive periodontal disease. The Open Dentistry Journal 10: 50-57.

\section{Your next submission with Juniper Publishers} will reach you the below assets

- Quality Editorial service

- Swift Peer Review

- Reprints availability

- E-prints Service

- Manuscript Podcast for convenient understanding

- Global attainment for your research

- Manuscript accessibility in different formats ( Pdf, E-pub, Full Text, Audio)

- Unceasing customer service

Track the below URL for one-step submission https://juniperpublishers.com/online-submission.php 